\title{
Making sense of the COVID-19 disruptions in incarnational ministry using Micah 6:8 as an interpretive framework
}

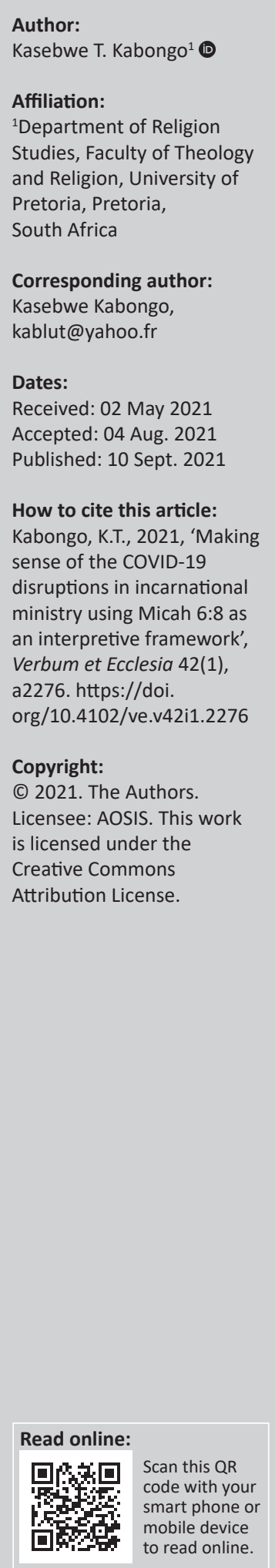

This is a case study reflecting on the impact of the coronavirus disease 2019 (COVID-19) disruptions on InnerCHANGE South Africa (ICSA hereafter), an incarnational ministry. Incarnation ministry is understood as an intentional effort to join God in the world, especially a community of poverty, live among the residents of that community, affirm their dignity and compassionately love them. This understanding is based on the values of justice activism, merciful love, and discipleship found in Micah 6:8. This article uses an interpretive framework based on the latter biblical passage to reflect on how the disruptions of COVID-19 has shaped the ICSA team. This reflection is guided by the question: how have the disruptions caused by COVID-19 challenged the relevance of incarnational ministry? This article found that in the case of ICSA, the disruptions have not only broadened its justice activism, but they have also taught it the importance of relief actions in its approach. They have also deepened its understanding of sabbath in connection with environmental care. They have exposed its local leadership development model bias against women. They have finally challenged it to adopt a hybrid model of virtual and face-to-face meetings in its discipleship efforts. The article concludes that disruptions are very challenging. However, they could be an opportunity to revisit and sharpen the existing priorities of an incarnational ministry.

Intradisciplinary and/or interdisciplinary implications: This is a missiological research that is enriched by insights from ecology, other fields of theology and journalism to imagine the relevance of an incarnational ministry in exceptional seasons.

Keywords: creation care; disruption; discipleship; incarnation; solidarity.

\section{Introduction}

Incarnation ministry can be understood as an intentional effort to join God in the world, especially a community of poverty, 'live among the residents of that community, affirm their dignity and compassionately love them' (John Perkins in Hayes 2006:12). It can also be seen as a tangible effort to reconcile people living on the margins of society to God and the rest of a society. It is also a vision to become 'like the people' someone or an entity is learning to reach (Hayes 2006:16).

This article is a case study reflecting on the relevance of the incarnational ministry principles of justice activism, merciful love, and discipleship in the midst of the disruptions caused by the coronavirus disease 2019 (COVID-19) pandemic. The pandemic 'has hobbled the global economy', and has disrupted the rhythm of life as we know it (Christakis 2020). In South Africa, disruptions started when the government declared a state of emergency and a countrywide lockdown from 27 March 2020. This case study investigates how the principles of incarnational ministry founded in Micah 6:8 have been affected by the COVID-19 disruptions. It uses the InnerCHANGE South Africa (ICSA) as a sample in this reflection. InnerCHANGE is an incarnational missional order that serves in communities of poverty. In South Africa, it is located in the township of Soshanguve located $40 \mathrm{kms}$ north of the city of Pretoria. This research is guided by the question: how have the disruptions caused by COVID-19 challenged the relevance of incarnational ministry? Micah 6:8 provides a helpful framework that guides the answer to this question.

\section{Micah 6:8 as an interpretive framework}

The Book of Micah was written during 'a season of great economic prosperity' in Israel (Tushima 2019:3). During that season, there was a general tendency towards 'lust for more' for the wealthy that resulted in the 'exploitation' of the general population which led to a lot of injustice in that 
society (Tushima 2019:4). It is in that context that prophet Micah was called to point out the injustice that was taking place. Therefore, 'the immediate context of Micah 6:8 is an indictment of the Lord against his people' who had normalised injustice around them (Becker 2020). It stresses that justice should lead 'to peace and reconciliation' in society (Thomson 2009:320). It also stresses that justice should lead to 'the maintenance of right relationships between persons within a community' (Tushima 2019:7). It posits that 'social justice is a promoter of peace, abundance and equality' in society (Madzokere 2018:372). It encourages Israel 'to be reconciled to God through repentance, faith and righteous living' (Ferreira 2017). It ends by making 'a call to discipleship' so that Israel could remain in tune with God's ways and implement them (Tushima 2019:3).

Micah 6:8 provides a platform to examine some important principles of incarnation ministry related to justice activism, merciful love and discipleship. This article reflects on the integrity of these principles in a season where everything seems to have been disrupted by COVID-19.

\section{Justice activism}

Micah 6:8 highlights the need for the church to be involved in society as a justice advocate for the poor because throughout the world no matter 'how friendly a justice system is, the poor are always worse off than the rich' (Chikane 2013:220). Many people living with poverty in Africa have an experience of seeing the triumph of the laws of their country over justice. They experience 'untransformed' laws whose custodians are people from above who do not experience 'the hardships and vulnerabilities' they regularly have to deal with (De Beer 2019:3). In these communities, there seems to be a daily perpetuation of 'new injustices and exclusions' (De Beer 2019:6). Hence, the need for the church to step in as a participant in making justice a reality for the poor.

A realistic approach to being involved in justice advocacy is through involvement in a specific context. Hence, Niemandt (2019:1) points out 'the importance of a theology of place' and sees 'incarnation as an appropriate missiological point of departure to reflect on' such a theology. This theology would convert the church 'from parochial self-absorption to an awareness of what God is doing for the salvation of [people] in the life of the world' (Bosch 1991:384). This awareness could help individual Christians to discern how to participate in bringing justice to the world around them. The sum of many acts of justice could help invent 'a new future for Africa' (Katongole 2011:23). Such a future will require the participation of all Africans as stakeholders. The church could participate in this endeavour by equipping its members to become justice activists.

Justice is critical at ICSA. It thrives on communicating justice in tangible ways. It has thus far limited its justice activism to human beings only. The coronavirus disease 2019 has challenged it to broaden its acts of justice to the whole creation, not human beings alone.

\section{Activism towards the whole creation}

The coronavirus disease 2019 has exposed how humans tend to only care for human life at the expense of the whole of creation. Few weeks into the lockdown, the author and his family were amazed on hearing unique bird sounds around their house. He also saw videos of mountain lions walking freely in some neighbourhoods of the United States. The lockdown seemed to have a positive impact on marine life also. Sea turtles, for instance, were now mating close off the shore near the surface of the water and their nests were undisturbed since people and dogs were banned from many beaches (Wvlt 2020). The lockdown seemed to have a positive impact on the revival in reproduction for many species that have been under threat of extinction (Wvlt 2020). Meylahn (2020:1) points out that COVID-19 has disrupted only the 'normal human life because other life seems to continue undisturbed'. The life of other creations seems to be coming back now that human life is locked down 'with oceans, rivers and air becoming cleaner' (Meylahn 2020:1). In the United Kingdom, for example, the daily carbon emissions fell by more than a third during their first lockdown in 2020 (Holland 2020).

The disruptions of COVID-19 have been a reminder of human beings' need to be in communion with other fellow creatures. Pope Francis (quoted by Van der Merwe 2020:5-6) says that 'our faith in Jesus impels us to live charity through concrete gestures capable of affecting our way of life, our relationships and the world around us'. In this postmodern era, human beings are usually put at the 'centre or crown of creation' at the expense of other creatures (Dolamo 2019:3). The Book of Genesis 1 and 2 reminds us that human beings were 'the last creatures created by God', yet they have taken domineering and sometimes suppressive roles within creation (Dolamo 2019:3). There seems to be a hierarchy of creatures that have been put in place which affirms the supremacy of human beings over other creatures. In that hierarchy, there is first God, 'followed by men, women, children and animals, and then at the bottom, the rest of creation' (Dolamo 2019:1). Such a worldview affirms human dominance and abuse over the rest of creation. InnerCHANGE South Africa has been guilty of this worldview. There is a lot of ecological destructions in its context that it has been silent about. In many instances, its staff, volunteers and beneficiaries have been contributing to the littering and polluting of their environment.

Dolamo (2019:1) posits that the original meaning of the creation stories is that humans are God's representative in creation, helping God in God's creative work'. He confirms that we are creatures with the mandate to exercise stewardship amongst fellows. However, we have done the opposite of that. Corbett and Fikkert (2009:61) say that '... before the fall, God established four foundational relationships for each person: a relationship with God, with self, with others, and with the rest of creation'. This led Geyser-Fouche and Serfontein (2019:9) to say that the whole creation is 'the work of the spirit of God, who vivifies the 
community of creation from which humans have also emerged'. This awareness has led ICSA to design a curriculum about creation care. Its goal is to develop its staff and beneficiaries into people who steward the environment around them. This stewardship highlights the importance of the sabbath.

\section{Sabbath as an act of justice}

The COVID-19 disruptions have put human lives under lockdown and has been a reminder of the importance of the sabbath so that the whole creation can flourish. Sabbath is understood as 'a pause in our normal routine' so that we can be liberated from the danger of slavery a routine may cause (Kopiec 2019:4). The coronavirus disease 2019 has forced humans to pause so that other creatures can find a healthier breathing space to thrive. This understanding has challenged the ICSA to self-introspect and think about the sabbath in its staff routines of flying and driving personal cars. This sabbath would mean an increased reliance on virtual meetings and cut down on flying and driving. It would also mean an increased reliance on public transport. It would finally mean changing the normal routine of office work and ministry with people, to include intentional time to clean the local environment. Such efforts would involve other community members who will be encouraged to participate in beautifying their neighbourhood. These efforts point out the importance of developing and nurturing local leaders as community stakeholders.

\section{Affirming local leadership as an act of justice}

Committing to affirm local leadership in African communities of poverty is a justice issue. Many residents of African communities of poverty have been told countless times that 'their place is at the bottom' of the world and the society (Baloyi 2020:1). They have learned to rely on solutions 'from above' designed outside their context (De Beer 2019:6). Perkins (2014:101) thinks that 'many years of slavery and colonialism, followed by generations of economic exploitation, political oppression, racial discrimination and educational deprivation', have created in Africans the feeling of inferiority, instability and total dependency. Therefore, an agency from below would be an antithesis of this disempowering legacy. Hence, an incarnational approach to ministry should not only challenge the church to join God in a community, but it should also challenge the residents of its local community to join God in building that community. Perkins (quoted in Hayes 2006) describes the goal of an incarnational ministry through this Chinese poem:

Go to the people, live among them, learn from them, love them, start with what they know, build on what they have, but of the best leaders, when their work is finished, their task is done, the people will remark, we have done it ourselves. (p. 11)

This 'can do' attitude will be cultivated from below through the nurturing of a leadership that could show 'a tremendous capacity to embrace, hold, and transform the experience of personal and communal suffering and tragedy into energy, commitment, and advocacy' for a just and equitable society (Katongole 2017:xiii). The efforts of creation care that the ICSA is envisioning, for instance, can only be successful if the local community is involved. InnerCHANGE South Africa is learning to prioritise its resources and time in the raising and equipping of local leaders. To date, all its staff and volunteers are locals, except the author. However, the majority of these leaders are men. During the very first lockdown, the team needed to help some elderly women in its neighbourhood. Those women's caregivers' movements were restricted by the government regulations because they lived in different townships. The shortage of women staff and volunteers was a handicap in the ICSA's acts of mercy. In the context of South Africa where women are usually marginalised at different levels of our society, the prioritisation of developing them as leaders, is an act of justice. An example of how women are marginalised in a society can be seen in the area of employment. According to Statistics South Africa (Stats SA 2018) the 'labour market is more favourable to men'. In 2018, 'women accounted for $43.8 \%$ ' of the labour force (Stats SA 2018). The ICSA's team has decided to prioritise the development of women leaders. The majority of the team beneficiaries are women. The coronavirus disease 2019 has challenged the team to question the effectiveness of its leadership formation when it comes to allowing women to 'realise their spiritual gifting' (James 2015:19). Prioritising the development of women has the potential to strengthen its service to other women and children. It may improve the quality of its ministries of mercy.

\section{Love mercy}

Micah 6:8 also highlights the task of the church to love mercifully. This task is connected to Jesus' instruction to his disciples found in John 13:35 to strive to be known by the way they love others. An incarnational way to express love is to 'stay near to the wounds of the world, singing over them and washing them, allowing the unsettling cry of pain to be heard' (Katongole \& Rice 2008:94). This expression is seen as a 'faithful presence' in a particular context (Niemandt 2019:4). This presence should put an 'emphasis on justice, mercy and humility before God...to avoid irrelevance to the great problems that affect humankind' (Wright 2010:110). It should catalyse the opening up of 'spaces that will be just and inclusive, particularly for the most vulnerable ...' (De Beer 2020:4). This is one of the ways to practise 'concrete solidarity with the poor' (De Beer 2020:4). This praxis could help the church recover the kind of worldview that postures it as an ambassador of God in the world.

The author sees the ministry of mercy not only as an individual obligation but also as a corporate endeavour' of the church (Pillay 2017:2). The ICSA runs ministries of mercy as an expression of this corporate endeavour. It believes in empowering local people to become the answer to their own prayers because it has learned that 'marginalised people often desire to be empowered', although they may not express that (Edwards 2020). It does not do relief actions. However, COVID-19 has challenged it to consider relief actions as a relevant act of mercy whenever it is relevant. 


\section{Relevance in acts of mercy}

The first COVID-19 lockdown unveiled the realities of poverty in South Africa. The township of Soshanguve was a sample of that reality. In that context, many people went hungry as soon as the lockdown was declared because they survive daily through part-time jobs. As a consequence, many of them needed immediate relief. Corbett and Fikkert (2009:104) define the immediate relief as the urgent and temporary provision of emergency aid to reduce immediate suffering from a natural or man-made crisis'. The ICSA's response to this need was to provide food parcels to the needy of its local community. Its action was inspired by God's command 'to show compassion to the poor' (Corbett \& Fikkert 2009:13). This action is also broadening its understanding of love mercy in learning to be involved in relief efforts. It is learning that paying attention to the current needs of local communities could prepare its residents 'to start playing an ongoing and long-lasting role' in their agency for community building since many local leaders are involved in these efforts (Van der Merwe 2020:5).

Relief efforts will be needed for a while as a consequence of COVID-19. According to the International Labour Organization, 'an estimated loss of 1.6 billion jobs in the informal economy' is predicted as a result of COVID-19 (Van der Merwe 2020:1-2). This prediction is felt like a reality in places like Soshanguve because many people lost their job as soon as the first lockdown was declared, and a lot more people continue to lose jobs as many businesses are closing down. It is argued that the COVID-19 pandemic may not only present a temporary shock, but it also has lasting implications for poverty rates in South Africa' (Schotte 2020:1). This sad reality challenges incarnation ministry entities to participate in immediate efforts to alleviate hunger and to make efforts to look for 'employment' for those who need jobs (Kabongo 2020:1). This could be in a tangible way good news for the vulnerable.

Relief efforts should be connected to awareness campaigns to minimise the spread of the virus. In places such as Soshanguve, there is low compliance with the COVID-19 rules and regulations. It can be argued that some of the rules are very difficult to comply with. However, it will take all of our efforts as humans to overcome the pandemic. For instance, ICSA staff and volunteers are learning to encourage their fellow community members not to live in fear, but be proactive in protecting themselves and others. Therefore, wearing something like a mask is a tangible sign of being considerate of others. It is not a sign of being scared of dying. The awareness message of the ICSA has been inspired by the song 'We are the world' (USA for Africa and various artists 1985). It has adapted it in the following words:

This crisis season is a time when the world must come together as one.

Some people died, some are hospitalised and many others sick in their homes.

It is time to lend a hand to life through our actions.

Your greatest gift to others is to protect and preserve their lives.
Let's stop pretending that this is just another disease,

Therefore, we should go on with our lives as if everything is normal.

Together, we are part of God's big family.

Let's love one another.

We are all children of the world

We are all affected by this pandemic

We can only overcome it if we stay together.

We can choose to live in solidarity

Or to be self-centred

Our choice will determine whether we are pro-life

Or pro-destruction

We are appealing to you to care

We are appealing to you to be pro-life

We need you to be healthy and participate in the building of our society.

A good way to start building our society would be to build households.

\section{Building households as an act of mercy}

One of the outcomes of the COVID-19 lockdown is the highlight of the realities of violence in South African households' (Mashele 2020:1). The ICSA staff have been called to intervene in many domestic violence cases in their context. Violence weakens family structures and has economic ramifications also. Riley (2016:82) stresses that communities with 'weak family structures are the slowest in economic progress'. The ICSA regularly experiences this weakness in its work with many children and teenagers. It has observed that many of those who come from functional families tend to have a good sense of discipline, selfconfidence and respect. Whereas those who come from dysfunctional families tend to have the opposite of these attributes. Mashele (2020:1) hopes that the COVID-19 disruptions could be an opportunity 'to rebuild [the] broken fabric of black' families because with the lockdowns many families get to spend a lot of time as a unit and could bond. Whereas under normal circumstances, parents spend the majority of their time working away from their children. The hope of a better future for Soshanguve households has challenged ICSA to design a discipleship curriculum that includes themes such as non-violence, building a functional partnership with the opposite gender, and adopting a little brother or sister in the neighbourhood. The fruits of this hope is still work in progress and challenges ICSA to remain humble while being perseverant on the journey.

\section{Walk humbly before your God}

Micah 6:8 finally talks about journeying with God as humble and teachable disciples. This discipleship is not only about personal contemplative life of obedience and deep intimacy with God, but also that of intentionally inviting other people to follow God. Discipleship could be understood as 'an 
invitation ... to participate in the Truine God's caring control of the whole of life ...' (Niemandt 2016:1). Discipleship should be holistic as Jesus' model was. The latter 'focused on the entire person being devoted to God. Through following Jesus, an individual is transformed by his presence, example and teaching' (Henry \& Swart 2021:6). Disciples are assessed by the way they 'impact the world around them' (Henry \& Swart 2021:6). This impact 'can be determined by how they are experienced as healing and solidarising communities' (De Beer 2019:6). The impact is even expected under conditions of 'duress' (Rowe 2020). This is why Cone (2011) says that:

[I]f you want to find people with deep faith rooted in the community of God's people going back to Abraham - learn from those who have suffered oppression and yet cling to their faith. (p. 7)

There is such evidence in the role the church played in the past to free Africans from 'oppressive' regimes (Resane 2016:3) Disciples are expected to bring 'all areas of their lives into conformity with the values of the Kingdom because God expects from his disciples an unconditional commitment to him' (Nel \& Schoeman 2019:6).

With the first lockdown, ICSA's discipleship efforts were initially interrupted because the team did them face to face. Later, the team experimented with a virtual model with some of the senior volunteers. This model has become a good alternative which has allowed the team not only to continue investing in its discipleship efforts in its context, but has also opened opportunities to discipleship with people living in different contexts. The lockdown restrictions have been eased and face-to-face interactions are allowed with a limited number of people. The ICSA now uses a hybrid model of discipleship in doing face-to-face interactions with those living in its contexts and virtual meetings with those who live outside its context. This hybrid model is still a work in progress that has broadened ICSA's capacity to reach out to those who are interested in its discipleship approach.

\section{Conclusion}

This case study reflected on the challenges of the disruptions caused by COVID-19. These disruptions have been a learning curve in the continued relevance of the values of justice, merciful love and humble walk before God. It used Micah 6:8 as an interpretive framework of the ICSA's commitment to justice activism, merciful love and discipleship. It pointed out the fruits of the COVID-19 disruptions such as the broadening of justice activism to the whole of creation, the deepening of the understanding of the sabbath, a leadership development programme with a bias towards men, the importance of relief actions in exceptional circumstances, intentionally towards the building of functional households and creative in the continuation of discipleship efforts. The research highlights the fact that disruptions are challenging. However, they could be an opportunity to revisit, broaden and sharpen the existing priorities of an incarnational ministry.

\section{Acknowledgements Competing interests}

The author declares that he has no financial or personal relationships that may have inappropriately influenced him in writing this article.

\section{Author's contributions}

K.T.K. is the sole author of this article.

\section{Ethical considerations}

This article followed all ethical standards for research without direct contact with human or animal subjects.

\section{Funding information}

This research received no specific grant from any funding agency in the public, commercial or not-for-profit sectors.

\section{Data availability}

Data sharing is not applicable to this article as no new data were created or analysed in this study.

\section{Disclaimer}

The views and opinions expressed in this article are those of the author and do not necessarily reflect the official policy or position of any affiliated agency of the author.

\section{References}

Baloyi, M.E., 2020, 'Black self-hatred: Regaining self-worth from decolonisation towards reconciliation in South Africa a practical theological appraisal', Theologia Viatorum 44(1), a33. https://doi.org/10.4102/tv.v44i1.33

Becker, P., 2020, A contextual understanding of Micah 6:8, viewed 02 July 2021, from https://creativecommons.org/licenses/by/2.0/.

Bosch, D., 1991, Transforming mission: Paradigm shifts in theology of mission, Orbis Books, New York, NY.

Chikane, F., 2013, The things that could not be said: From AIDS to Zimbabwe, Picador Africa, Johannesburg.

Christakis, N., 2020, Responding to covid-19: Nicholas Christakis on fighting covid-19 by truly understanding the virus, viewed 24 September 2020, from https://www. economist.com/by-invitation/2020/08/10/nicholas-christakis-on-fighting-covid19-by-truly-understanding-the-virus.

Cone, J.H., 2011, The cross and the lynching tree, Orbis books, Maryknoll, NY.

Corbett, S. \& Fikkert, B., 2009, When helping hurts: How to alleviate poverty without hurting the poor and yourself, Moody Publishers, Chicago, IL.

De Beer, S.F., 2019, 'Faith-based agency and theological education: A failed opportunity?', HTS Teologiese Studies/Theological Studies 75(4), a5541. https:// doi.org/10.4102/hts.v75i4.5541

De Beer, S.F., 2020, 'Homelessness and Covid-19 in the City of Tshwane: Doing liberation theology undercover - A conversation with Ivan Petrella', HTS Teologiese Studies/Theological Studies 76(1), a6209. https://doi.org/10.4102/hts.v76i1.6209

Dolamo, R.T.H., 2019, 'A Trinitarian theology of creation: An ethical perspective', HTS Teologiese Studies/Theological Studies 75(1), a5421. https://doi.org/10.4102/hts. v75i1.5421

Edwards, D., 2020, Might from the margins: The gospel's power to turn the tables on injustice, Herald Press, Portland, OR.

Ferreira, J., 2017, Micah: A pastoral and contextual commentary, Langham Publishing, London.

Geyser-Fouche, A. \& Serfontein, B., 2019, 'Creation order in sapiential theology: An ecological-evolutionary perspective on cosmological responsibility', HTS Teologiese Studies/Theological Studies 75(3), a5157. https://doi.org/10.4102/hts. v75i3.5157

Hayes, J.B., 2006, Sub-merge: Living deep in a shallow world: Service, justice and contemplation among the world's poor, Regal, Ventura. 
Henry, D. \& Swart, M.F., 2021, 'Beyond post-Christendom discipleship of the Evangelical Church in the United Kingdom: A study of the gospel of Matthew in the transformissional and holistic perspective', Verbum et Ecclesia 42(1), a2229. the transformissional and holistic persp
https://doi.org/10.4102/ve.v42i1.2229

Holland, L., 2020, The UK's daily carbon emission falls by a third during lockdown, viewed 08 May 2020, from https://news.sky.com/story/coronavirus-carbonvisions-fall-by-more-than-a-third-in-lockdown-11983721.

James, C.C., 2015, Half the church: Re-capturing God's vision for women, Zondervan, Grand Rapids, MI.

Kabongo, K.T.L., 2020, 'A partnership for prosperity agency: A case study of InnerCHANGE South Africa', Theologia Viatorum 44(1), a48. https://doi. org/10.4102/TV.v44i1.48

Katongole, E., 2011, The sacrifice of Africa. A political theology for Africa, William B. Eerdmans Publishing Company, Grand Rapids, MI.

Katongole, E., 2017, Born from lament: The theology and politics of hope in Africa, William B. Eerdmans Publishing Company, Grand Rapids, MI.

Katongole, E. \& Rice, C., 2008, Reconciling all things: A Christian vision for justice, peace and healing, IVP Books, Downers Grove, IL.

Kopiec, P., 2019, 'The idea of the biblical economics: Utopia or chance in the face of the contemporary transformations of the sphere of work', HTS Teologiese Studies/ Theological Studies 75(4), a5164. https://doi.org/10.4102/hts.v75i4.5164

Madzokere, N., 2018, “'A prophet for the poor?" A contextual reading of the book of Micah vis-a-vis poverty alleviation efforts in Zimbabwe', in M. Mawere (ed.), Jostling between 'mere talk' and blame game?: Beyond Africa's poverty and underdevelopment game talk, p. 371, Langaa Research \& Publishing CIG, Mankon, Bamenda.

Mashele, P., 2020, Coronavirus a chance to rebuild the broken fabric of black family life, Sowetan Monday, May 04, viewed 05 May 2020, from https://www.sowetanlive. co.za/opinion/columnists/2020-05-04-coronavirus-a-chance-to-rebuild-brokenfabric-of-black-family-life/.

Meylahn, J.-A., 2020, 'Being human in the time of Covid-19', HTS Teologiese Studies/ Theological Studies 76(1), a6029. https://doi.org/10.4102/hts.v76i1.6029

Nel, M. \& Schoeman, W.J., 2019, 'Rediscovering "disciplemaking” and the role of faithsharing', HTS Teologiese Studies/Theological Studies 75(4), a5119. https://doi. org/10.4102/hts.v75i4.5119
Niemandt, C.J.P., 2016, 'Rediscovering joy in costly and radical discipleship in mission', HTS Teologiese Studies/Theological Studies 72(4), a3831. https://doi.org/10.4102/ hts.v72i4.3831

Niemandt, C.J.P., 2019, 'Rooted in Christ, grounded in neighbourhoods - A theology of place', Verbum et Ecclesia 40(1), a1997. https://doi.org/10.4102/ve.v40i1.1997

Perkins, J.M., 2014, Let justice roll down, Baker Books, Grand Rapids, MI.

Pillay, J., 2017, 'The church as a transformation and change agent', HTS Teologiese Studies/Theological Studies 73(3), 4352. https://doi.org/10.4102/hts.v73i3.4352

Resane, K.T., 2016, 'Ichabod - The glory has departed: The metaphor showing the church's prophetic failure in South Africa', Pharos Journal of Theology 97(1), 1-12.

Riley, J.L., 2016, Please stop helping us: How liberals make it harder for blacks to succeed, Encounter Books, New York, NY.

Rowe, S.W., 2020, Healing racial trauma: The road to resilience, InterVarsity Press, Downers Grove, IL.

Schotte, S., 2020, COVID-19 in South Africa: A temporary shock or lasting poverty trap?, viewed 12 April 2021, from http://www.chronicpovertynetwork.org/ blog/2020/4/23/covid-19-in-south-africa-temporary-shock-or-lasting-povertytrap.

Stats SA, 2018, How do women fare in the South African labour market?, viewed 03 July 2021, from http://www.statssa.gov.za/?p=11375.

Thomson, H., 2009, 'Satisfying justice', International Journal of Public Theology 3(3), 319-338.https://doi.org/10.1163/156973209X438274

Tushima, C.T.A., 2019, 'Advancing justice in the search for peace: An exegetical study of Micah 6:8 as a recipe for peace in Africa', Verbum et Ecclesia 40(1), a1961. https://doi.org/10.4102/ve.v40i1.1961

USA for Africa and Various Artists, 1985, We are the world, Quincy Jones, Columbia/ CBS Records, New York, NY.

Van der Merwe, J.M., 2020, 'Poverty and the COVID-19 pandemic: A challenge to the church', HTS Teologiese Studies/Theological Studies 76(1), a6621. https://doi. org/10.4102/hts.v76i1.6221

Wright, C.J.H., 2010, The mission of God's people: A biblical theology of the church's mission: Biblical theology of life, Zondervan, Grand Rapids, MI.

Wvlt, 2020, Many species are enjoying the lockdown, viewed 07 May 2020, from https://www.wvlt.tv. 